\title{
The Role of Bone Stem Cell Niches in Bone Metastasis
}

\author{
Roberto Tamma*(D), Tiziana Annese (D) and Domenico Ribatti *(D) \\ Department of Basic Medical Sciences, Neurosciences and Sensory Organs, Section of Human Anatomy and \\ Histology, University of Bari Medical School, 70124 Bari, Italy; tiziana.annese@uniba.it \\ * Correspondence: Roberto.tamma@uniba.it (R.T.); domenico.ribatti@uniba.it (D.R.); \\ Tel.: +39-080-5478-323 (R.T.); +39-080-5478-326 (D.R.); Fax: +39-080-5478-310 (R.T. \& D.R.)
}

Received: 30 September 2020; Accepted: 29 October 2020; Published: 31 October 2020

\begin{abstract}
In post-natal life, stem cells contribute to the preservation of many tissues. In adults, stem cells remain localized, in particular, specialized microanatomical areas named as niches, which are crucial in the control of stem cell quiescence and activity through the production of many regulatory signals. Bone physiologically includes both the endosteal niche and the vascular niche, which are involved in the attraction, retention and release of the residing stem cells during the formation of new vessels as well as in the control of the differentiation of bone-forming osteoblasts and bone-resorbing osteoclasts. In tumors, cancer cells are able to take control of the niches to support all the stages of the tumorigenesis, transforming them in the so-called pre-metastatic and metastatic niches. Hence, there is emerging importance of the interactions between cancer cells, bone cells and niches in driving metastatic progression. This review article summarizes the literature data concerning the role of bone vascular and endosteal niches in the regulation of bone metastasis, focusing on their cellular and molecular interactions and the potential therapeutic approaches.
\end{abstract}

Keywords: bone staminal niche; bone metastasis; endosteal niche; pre-metastatic niche; vascular niche

\section{Introduction}

Metastasis is a multi-phase process that requires the detachment of cancer cells from the primary tumor, their migration through the adjacent tissue, then entering the bloodstream and reaching the distant organs where they find the microenvironment suitable for surviving and proliferating [1,2]. Currently it is believed that metastatic process is responsible for a great percentage of cancer-related death [3].

Bone is the third most common site of metastatic occurrence after lung and liver. Solid tumors more frequently metastasize to the bone [4]. Most bone metastases originate from prostate, breast and lung cancer. It is estimated that nearly $70 \%$ of breast cancer patients and $90 \%$ of prostate cancer patients that die from disease have bone metastases but other common bone metastasizing cancers include the bladder, renal, thyroid, sarcoma and lymphomas [5].

In this short review article, we try to elucidate some aspects about the interactions between metastatic cells and the microenvironment present in bone staminal niches because this could be very useful to elaborate strategies that can target these interactions and prevent or eradicate metastatic disease.

\section{Pre-Metastatic Niche}

Kaplan and coworkers were the first to demonstrate that sites in which a metastasis occurs are pre-conditioned for colonization of circulating tumor cells. These sites are supportive to the survival and outgrowth of tumor cells before their arrival at these sites and are termed as pre-metastatic niches (PMNs) [6]. 
It is well-known that the tumor microenvironment (TME) and metastatic process are interconnected. TME is complex tissue environments in which the tumor cells are surrounded by various types of cells, extracellular matrix (ECM) components and a vascular network involved in the regulation of tumor initiation, progression and metastasis $[7,8]$.

The process leading to organ tropism in tumor metastasis has been extensively investigated. Up to now the "seed and soil" hypothesis elaborated by Stephen Paget remain valid. He proposed that metastasis is the result of favorable interactions between metastatic tumor cells ("seed") and the target organ microenvironment (the "soil") $[9,10]$.

In addition to inducing tumor growth, these interactions can impair the function of bone cells, leading to increased osteoclast-mediated bone resorption or excessive increased bone formation. In this context, bone metastases can be classified into osteolytic, osteoblastic and a mixed phenotype of both [11,12]. The osteolytic lesions are characterized by the destruction of normal bone by osteoclasts and not due to the direct involvement of tumor cells. During this process, parathyroid hormone-related peptide (PTHrP) and the receptor activator of nuclear factor- $\mathrm{kB}$ ligand (RANKL) play a crucial role in osteolytic bone metastasis [13]. It is not clear if the bone microenvironment induces cancer cells to express PTHrP or the latter have an intrinsic higher PTHrP expression. Osteoblastic metastasis is characterized by deposition of new bone. Many factors are involved during osteoblastic metastasis, in particular, transforming growth factor (TGF), bone morphogenetic proteins (BMPs) and endothelin-1 [14]. In mixed metastasis, present in breast cancer [13,15], gastrointestinal cancer and squamous cancer $[16,17]$, both types of lesions are present.

The most common skeleton metastases are the osteolytic bone lesions that are typical of breast and lung carcinoma as well as hematological malignancies such as multiple myeloma. Although some cancer cells such as the breast cancer cells exert osteoclast-like activities and are able to resorb bone [18], the bone resorption process caused by osteolytic metastases is due to the positive modulation of osteoclasts by cancer cells [19]. It has been established that the secretion of ECM-modifying enzyme lysyl oxidase (LOX) in osteolytic lesions is correlated to the hypoxia, which is essential for the formation of PMN [20]. Moreover, PTHrP [21], interleukin-6 (IL-6) [22] and matrix metalloproteinases (MMPs) [22] are known to stimulate osteoblasts to release RANKL, which in turn induces osteoclast differentiation. Literature data has shown that these factors stimulate the survival, the growth and continued pro-osteolytic signaling of cancer cells [23]. Osteoblastic bone metastasis is often associated with prostate cancer, although it can occur in breast cancer and rarely in a sclerotic variant of myeloma [24], as well as in other malignancies [25]. These types of metastasis may induce bone fractures mainly in the vertebral bodies and in the proximal ends of the long bones due to both alteration of bone architecture and the activation of osteoclasts [26]. In osteoblastic metastases occurring in prostate cancer, it is thought that primary tumor-secreted factors such as wingless-type mouse mammary tumor virus integration site family, member 1 (WNT), BMPs, fibroblast growth factor (FGF), insulin-like growth factor 1 and 2 (IGF1 and IGF2), endothelin-1, prostate-specific antigen (PSA) and vascular endothelial growth factor A (VEGFA) may be involved in the regulation of the osteoblastic pre-metastatic niche [27].

\section{Bone Staminal Niche and Metastasis}

The bone marrow (BM) cell microenvironment includes stem and progenitor cells, differentiated hematopoietic lineage cells, vascular cells and bone cells like osteoblasts [28]. Moreover, physiologically bone contains two staminal niches localized in the BM cavity, including the endosteal and the vascular niches [29].

The endosteal niche is localized in the internal bone shell surface [30], in particular, close to the endocortical and trabecular surfaces [29], and include two types of osteoblastic cells, the actively bone-producing osteoblasts and a type of early osteoblast termed spindle-shaped N-cadherin+ CD45osteoblastic cells (SNO) [31]. There is a crosstalk between SNO cells and hematopoietic stem cells (HSCs), which regulate the cycle, the fate and activity of both SNO and HSC [29] (Figure 1a). 


\section{a}

endosteal niche

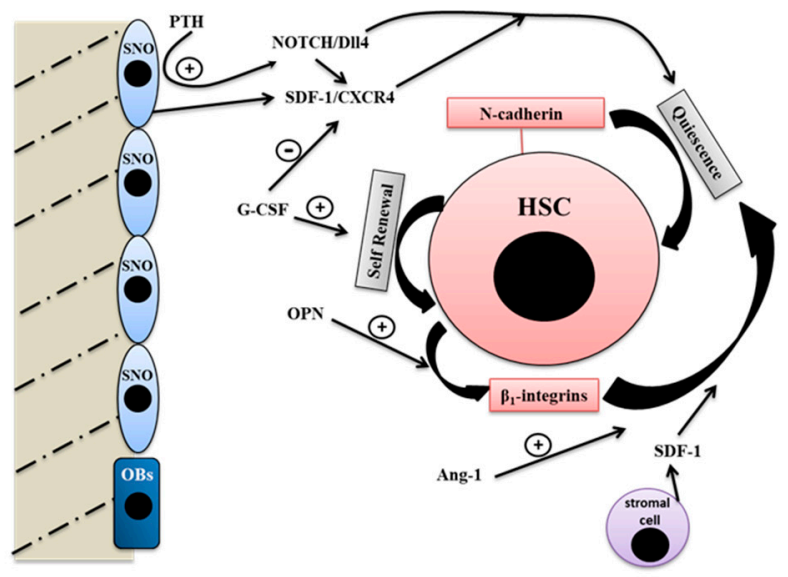

b vascular niche

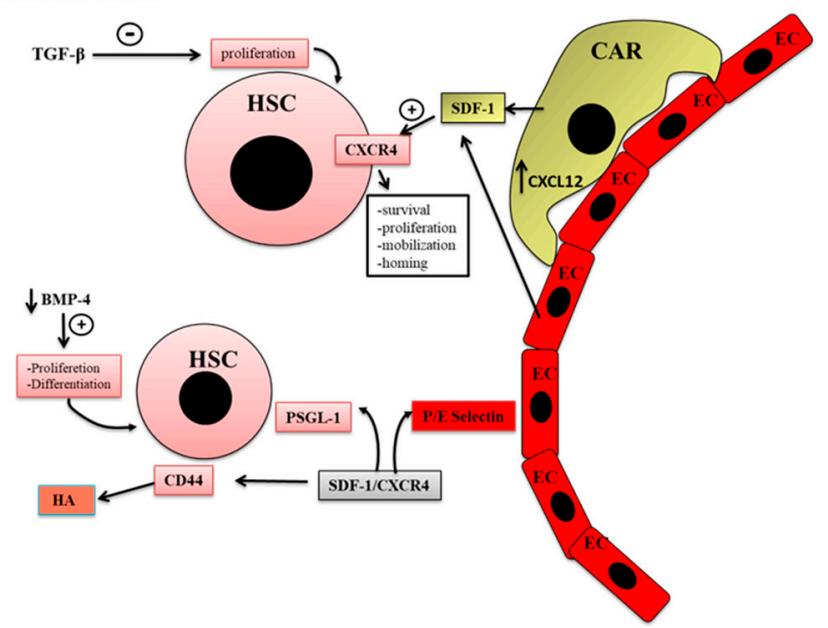

Figure 1. Bone staminal niches (adapted with permission from [29], MDPI, 2017). (a) The endosteal niche includes two types of osteoblastic cells, the actively bone-producing osteoblasts (OB) and a type of early osteoblast termed spindle-shaped N-cadherin+ CD45- osteoblastic cells (SNO). The intercommunication existing between SNO cells and hematopoietic stem cells (HSCs) regulate the cycle, the fate and activity of both SNO and HSC. In the endosteal niche, stem cells, progenitor cells, stromal cells, growth factors and extracellular matrix (ECM) molecules participate to the regulation of hematopoiesis. (b) HSC niche is localized in the center of the bone marrow (BM) cavity close to the sinusoidal endothelium to form the so-called vascular niche. The blood vessels of the BM participate in the regulation of hematopoiesis as well as stem cell mobilization and homing. Endothelial cells are surrounded by adventitial cells, also called CXCL12-abundant reticular (CAR) cells. The closeness between sinusoidal endothelial cells and HSCs is very important for their maturation and for the hematopoietic process.

During tumor metastasis, cancer cells that arrive and establish at a pre-metastatic niche take control of the physiological functions exerted by the staminal niches in order to support their own functions, varying from tumor cell dissemination to dormancy, relapse and growth [32]. Kapland et al. demonstrated that VEGF receptor 1 (VEGFR1)-positive BM-derived hematopoietic progenitor cells migrate and form cellular clusters in tumor-specific pre-metastatic sites [33] (Figure 2). 


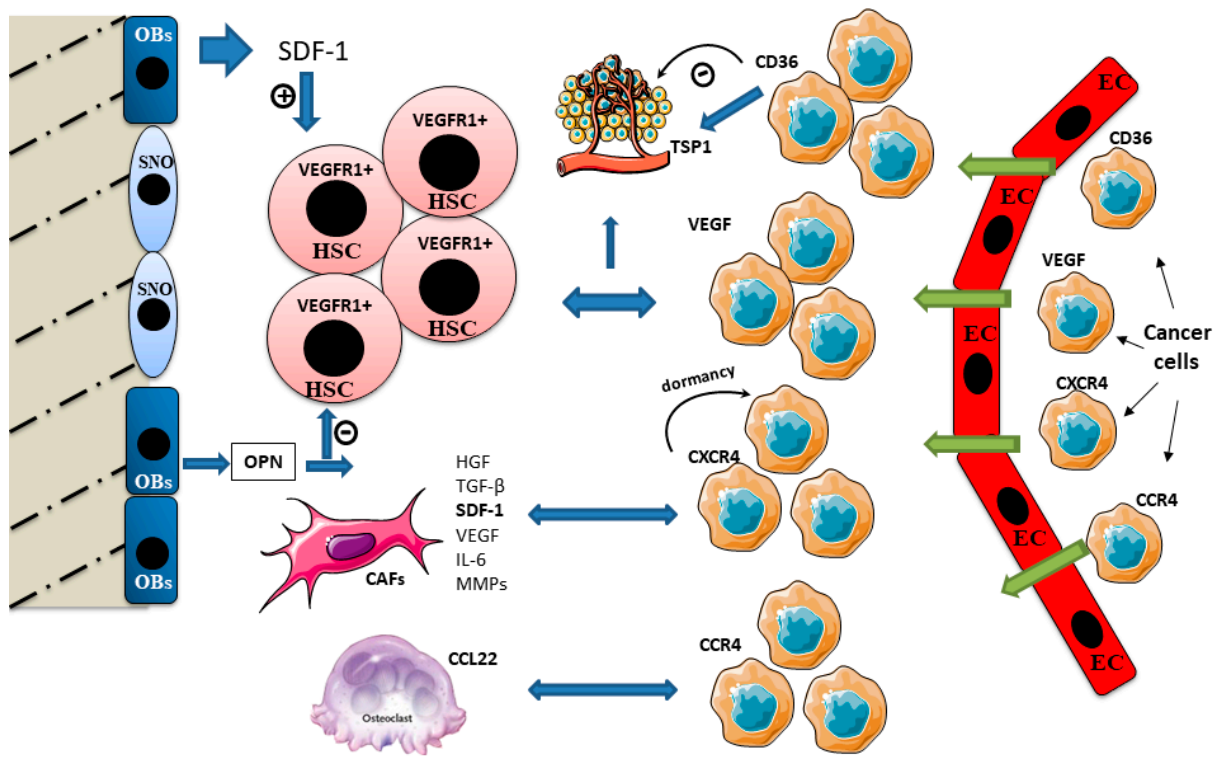

Figure 2. Cross talk signaling in bone niches during bone metastasis. Immature osteoblasts express higher levels of stromal-derived factor 1 (SDF-1) and support HSC maintenance. SDF-1 is involved in the bone tropism of bone metastasizing cancers. Cancer cells expressing C-X-C chemokine receptor type 4 (CXCR4) home to bone and reside in the pre-metastatic niche. SDF-1 induces cancer cell dormancy after it anchors the cancer cells in the niche. Cancer-associated fibroblasts (CAFs) release numerous factors such hepatocyte growth factor (HGF), TGF- $\beta$, SDF-1, VEGF, IL- 6 and MMPs, affecting tumor growth, invasion, metastasis and therapy resistance. TRAP-positive osteoclasts express C-C motif chemokine ligand 22 (CCL22) which promotes bone metastasis, attracting cancer cells expressing its ligand C-C chemokine receptor type 4 (CCR4). Osteopontin (OPN) binds the extracellular matrix and stimulates HSC and osteoclast adherence to the bone matrix. OPN is a negative regulator of HSC cycling. High OPN expression has been found within metastatic cells and in the surrounding tissue stroma. Thrombospondin (TSP1) assists the cancer cell invasion. It strongly stimulates cancer cell migration, and this effect is correlated to the expression of its cellular ligand CD36, also involved in TSP1 antiangiogenic activity.

Many leukemia cells, including acute myeloid leukemia (AML), chronic myeloid leukemia (CML) and acute lymphoblastic leukemia (ALL), produce high levels of VEGF and express VEGF receptors (VEGFRs) [34,35]. VEGFR1 is involved in targeting of these cells within the BM, and in the regulation of their survival, as well as their passage into the circulation [36].

Cancer cells secrete numerous factors, including VEGF and placental growth factor (PlGF), that induce local changes in tumor stroma, and activate the BM-derived cells to support angiogenesis. VEGFR signaling leads to the recruitment of hematopoietic stem cells (HSCs) and endothelial precursor cells (EPCs) expressing VEGFR2 to neoangiogenic sites in the tumor [36].

We have previously discussed the crucial role of osteoblasts located in the endosteal niche in the regulation of the activity and fate of HSCs [29]. HSCs which adhere to osteoblasts express angiopoietin receptor-2 (Tie-2), while the lining cells in BM synthesize Ang-1. The activation of Tie-2 by Ang- 1 induces the adhesion of the two cell types and Ang- 1 enhances the survival of HSCs [37]. In addition, it has been demonstrated that another mesenchymal-derived cell-type resident in the endosteal niche involved in the formation and progression of bone metastasis includes fibroblasts. CAFs form a supportive microenvironment that promotes tumor progression by regulating ECM deposition, recruitment of inflammatory mediators and epithelial differentiation [38,39]. CAFs are one of the most abundant stromal cell types in breast cancer and are associated with poor prognosis [40]. They release numerous factors that include hepatocyte growth factor (HGF), TGF- $\beta$, stromal-derived factor 1 (SDF-1), VEGF, interleukin-6 (IL-6), in addition to MMPs that affect several hallmarks of cancer, 
including tumor growth, invasion, metastasis and therapy resistance [41,42]. Human BM-derived mesenchymal stem cells (MSCs) stimulated with conditioned medium from breast cancer cells can acquire a CAF-like phenotype [43] (Figure 2). SDF-1 signaling seems to be implicated in tumor metastasis tropism. SDF-1 gradients regulate HSC retention within BM niches, and cancer cells expressing SDF-1 receptor (CXCR4) home to bone and reside in the pre-metastatic niche.

Immature osteoblasts in the endosteal niche express higher levels of SDF-1 and support HSC maintenance [29]. SDF-1 is involved in the bone tropism of bone metastasizing cancers such as breast, ovarian, prostate and brain. Interestingly, neutralization of the SDF-1/CXCR4 axis can block prostate metastasis [44-47]. It is well-known that osteoblasts produce osteopontin (OPN), that bind the extracellular matrix at the endosteal surface and stimulate HSC and osteoclast adherence to the bone matrix. In the endosteal niche, OPN is a negative regulator of HSC cycling. Increased OPN expression has been found within metastatic cells and in surrounding tissue stroma. It is thought that OPN is involved in metastatic spread of breast, prostate, colon and liver cancers [48,49] (Figure 2).

It has been well-evidenced that SDF-1 induces pro-survival signaling in CXCR4-positive AML cells. The inhibition of the SDF-1a/CXCR4 pathway led to chemo-sensitization of AML cells [50].

A relationship between SDF-1 and Notch has been found [51]. Cell surface, total protein and mRNA levels of CXCR4, the principal signaling receptor for SDF-1, were significantly decreased in Notch ligand or Delta-like ligand 4 (Dll4)-transduced endothelial cells, which is attributable to a significant reduction of CXCR4 promoter activity [40]. In addition, HSC quiescence and retention in the marrow niche is facilitated by the interaction between Notch1 and jagged canonical Notch ligand 1 (JAG1) or Delta-like ligand 4 (Dl14), expressed by niche cells [52]. Notch has been linked to $\beta$-catenin-dependent tumorigenesis. The expression of JAG1 in HSC is correlated to the mutation in the $\beta$-catenin gene in osteoblasts [53], and the expression levels of $\beta$-catenin in osteoblasts is considered as a marker for the prognosis of hematological malignancies $[54,55]$.

SDF-1 expression is also induced by osteopontin (OPN). OPN expressed by osteoblasts is highly concentrated at the endosteal interface of bone and hematopoietic tissue [45,49], and is essential for the trans-marrow migration and lodgment of HSC [56]. OPN is involved in the regulation of each critical step of the process of metastasis $[57,58]$, and correlation has been established between OPN and the metastatic spread of breast, prostate, colon and liver cancers [48,49] (Figure 2). In this context, the role of HSC in metastatic cells recruitment and in the regulation of dormancy of disseminated tumor cells is becoming of increasing importance in the formulation of new prostate cancer-targeted therapies [59].

Osteoclasts contribute to cancer cells tropism. It has been demonstrated that differentiating TRAP-positive osteoclasts produces the C-C motif chemokine ligand 22 (CCL22) that promotes bone metastasis of lung cancer cells expressing its ligand C-C chemokine receptor type 4 (CCR4) (Figure 2). As discussed in our previous work, the HSC niche is localized in the center of the BM cavity close to the sinusoidal endothelium to form the so-called vascular niche. The blood vessels of the BM not only constitute the wall that separates the hematopoietic compartment from the peripheral circulation but are able to regulate hematopoiesis as well as stem cell mobilization and homing. It has been hypothesized that when cancer cells arrive to bone, in the vascular niche they compete with HSCs for their niche $[29,60]$.

Adhesion of cancer cells to the endothelium seems to be crucial in metastatic process [61]. In this context, the vascular niche has been proposed to function as a "pro-dormancy" niche, maintaining the cancer cells quiescent. Notch2 signaling seems to regulate cellular activity in breast cancer bone metastasis, inducing their dormancy. The medullary vascular sinuses are lined with endothelial cells and surrounded by adventitial cells, a small population of cells with long processes, expressing high amounts of CXCL12 (SDF-1), called CXCL12-abundant reticular (CAR) cells (Figure 1b).

SDF-1 also seems to induce cancer cell dormancy after it anchors the cancer cells in the niche. Moreover, endothelial cells surrounding the microvasculature also express thrombospondin (TSP1), which seems to induce breast cancer cell quiescence, and lung metastatic cells express high TSP1 levels [44]. TSP1 induced cell migration in several tumor cell lines, suggesting its function in assisting 
the cancer cell invasion in different tumor types [62,63], and this effect is correlated to the expression of CD36, which is also involved in TSP1 antiangiogenic activity [64] (Figure 2). While a stable vasculature promotes dormancy, the active sprouting neovasculature has been proposed to release cancer cells from the dormant state and support micrometastases growth via TGF- $\beta$ and periostin [65].

Periostin was initially isolated from a mouse calvaria-derived osteoblast cell line. In bone, it modulates cell adhesion and is involved in bone formation and reparation [66]. In addition, periostin is considered a prognostic marker of many kinds of tumors, including non-small-cell lung carcinomas, ovarian carcinoma, oral cancer and head and neck squamous cell carcinoma [67].

A molecular mechanism to metastasis initiation involves cellular plasticity mediated by epithelial-to-mesenchymal and mesenchymal-to-epithelial transitions (EMT and MET) [68]. EMT lead to the acquisition of mesenchymal features and is considered essential for metastasis [69]. Metastatic tumors often reflect the epithelial state of the primary ones and EMT is required during metastatic colonization [68,70]. In prostate cancer, the EMT plays an important role in osteblastic metastases [2,71]. The interactions between prostate cancer cells and osteoblasts and metastasis formation are mediated by many factors, including TGF- $\beta$, BMP, insulin growth factor (IGF), FGFs and WNTs [72,73]. Factors inducing osteoclastic bone resorption, including PTHrP, lead to EMT in prostate cancer and subsequently an aggressive and bone metastatic phenotype [74,75]. MET is involved in the colonization of disseminate tumor cells belonging to primary tumors at the secondary site. Breast cancer downregulation of the E-cadherin gene (CDH1) due to the methylation of its promoter is associated with poor prognosis and metastasis [76]. It has been demonstrated that MET is involved in the demethylation of the CDH1 promoter at the secondary site [77]. It is suggested that the bone vascular niche could contain stromal signals used by cancer cells during bone metastasis $[65,78]$. In this context, the binding of bone vascular niche E-selectin to cancer cells promotes bone metastasis by inducing MET and activating Wnt signaling. These results underline the role of E-selectin as a component of the vascular niche critical for metastatic colonization in bone [79].

\section{Concluding Remarks and Therapeutic Perspectives}

Mortality during metastatic disease is mainly associated with the lack of effective treatments. Moreover, chemotherapy could also be involved in the promotion of metastasis formation. Bone is the third most common site of metastatic occurrence. BM microenvironment cell components include vascular and bone cells, stem cells, progenitor cells and differentiated hematopoietic lineage cells. In addition, the BM comprises two staminal niches called the endosteal and vascular niche that are involved in the regulation of activities of the residing stem cells during both angiogenesis and bone cell differentiation [80]. Endosteal and vascular niches are also correlated to predetermined microenvironments in which metastasis frequently occurs and corresponds to 'pre-metastatic niches'.

The deepening of study of the BM microenvironment and the signals influencing it could be useful for the recognition of progress, prognosis, relapse and treatment of bone metastases [81].

For example, the inhibition of the CXCL12/CXCR4 pathway resulted in blockage of pro-survival signaling between the leukemic cells and its stroma and increases the mobilization of leukemic cells from their protective niches, making them more sensitive to conventional chemotherapy $[82,83]$. On the other hand, cancer treatments like chemotherapy and radiotherapy induce an impairment of the hematopoietic stem/progenitor cells and BM stromal cells $[84,85]$. In hematological malignancies, including leukemia and lymphoma, the rearrangements of BM niches that lead to the induction of chemoresistance have been observed [86,87]. As previously discussed, the pre-metastatic niche draws VEGFR1-positive myeloid cells and, consequently, cancer cells to initiate metastasis. Recent studies have demonstrated that molecules inducing the blockage of VEGF in PMN could prevent metastasis [88]. Moreover, TSU68, an inhibitor of vascular endothelial growth factor receptor 2, platelet-derived growth factor receptor beta (PDGFB) and fibroblast growth factor receptor 1 (FGFR1) modulated the PMN and decreased the incidence of metastasis in animal models of colon cancer [89]. This scenario constitutes an interesting stimulus to further investigate the alterations in bone metastatic 
niches induced by cancer therapies and their influence on bone metastatic relapse. This could lead to deepening the mechanisms involved in the control of cancer progression and could be very helpful in elaborating new clinical strategies of cancer therapies.

Author Contributions: Writing—original draft preparation, R.T.; Figures elaboration, T.A.; Supervision, D.R. All authors have read and agreed to the published version of the manuscript.

Funding: This research received no external funding.

Conflicts of Interest: The authors declare no conflict of interest.

\section{Abbreviations}

\begin{tabular}{|c|c|}
\hline ALL & acute lymphoblastic leukemia \\
\hline AML & acute myeloid leukemia \\
\hline Ang-1 & angiopoietin-1 \\
\hline $\mathrm{BM}$ & bone marrow \\
\hline BMP & bone morphogenetic protein \\
\hline CAFs & cancer-associated fibroblasts \\
\hline CAR & CXCL12-abundant reticular cells \\
\hline CCL22 & C-C motif chemokine ligand 22 \\
\hline CCR4 & C-C chemokine receptor type 4 \\
\hline CDH1 & E-cadherin gene \\
\hline CML & chronic myeloid leukemia \\
\hline CXCR-4 & C-X-C chemokine receptor type 4 \\
\hline Dll4 & Delta-like ligand 4 \\
\hline EC & endothelial cells \\
\hline ECM & extracellular matrix \\
\hline EMT & epithelial-to mesenchymal transition \\
\hline EPCs & endothelial precursor cells \\
\hline FGFR1 & fibroblast growth factor receptor 1 \\
\hline G-CSF & granulocyte colony-stimulating factor \\
\hline HA & hyaluronic acid \\
\hline HGF & hepatocyte growth factor \\
\hline HSC & hematopoietic stem cells \\
\hline IGF1 and IGF2 & insulin-like growth factor 1 and 2 \\
\hline IL-6 & interleukin-6 \\
\hline JAG1 & jagged canonical Notch ligand 1 \\
\hline LOX & lysyl oxidase \\
\hline MET & mesenchymal-to-epithelial transitions \\
\hline MMPs & matrix metalloproteinases \\
\hline MSCs & mesenchymal stem cells \\
\hline OBs & osteoblasts \\
\hline OPN & osteopontin \\
\hline PDGFB & platelet-derived growth factor receptor beta \\
\hline PlGF & placental growth factor \\
\hline PMNs & pre-metastatic niches \\
\hline PSA & prostate-specific antigen \\
\hline PSGL-1 & glycoprotein ligand-1 \\
\hline PTH & parathyroid hormone \\
\hline PTHrP & parathyroid hormone-related peptide \\
\hline RANKL & receptor activator of nuclear factor- $\mathrm{kB}$ ligand \\
\hline SDF-1 & stromal cell-derived factor- 1 \\
\hline SNO & spindle-shaped N-cadherin + CD45 osteoblastic cells \\
\hline TGF- $\beta$ & transforming growth factor- $\beta$ \\
\hline TSP1 & thrombospondin \\
\hline
\end{tabular}


VEGFA vascular endothelial growth factor A

VEGFR1 VEGF receptor 1

VEGFR2 VEGF receptor 2

WNT wingless-type MMTV integration site family, member 1

\section{References}

1. Seyfried, T.N.; Huysentruyt, L.C. On the origin of cancer metastasis. Crit. Rev. Oncog. 2013, 18, $43-73$. [CrossRef] [PubMed]

2. Gao, Y.; Bado, I.; Wang, H.; Zhang, W.; Rosen, J.M.; Zhang, X.H. Metastasis Organotropism: Redefining the Congenial Soil. Dev. Cell 2019, 49, 375-391. [CrossRef] [PubMed]

3. Khan, I.; Steeg, P.S. Metastasis suppressors: Functional pathways. Lab. Investig. 2018, 98, 198-210. [CrossRef] [PubMed]

4. Guo, Y.; Mao, S.; Zhang, A.; Wang, R.; Zhang, Z.; Zhang, J.; Wang, L.; Zhang, W.; Wu, Y.; Ye, L.; et al. Prognostic Significance of Young Age and Non-Bone Metastasis at Diagnosis in Patients with Metastatic Prostate Cancer: A SEER Population-Based Data Analysis. J. Cancer 2019, 10, 556-567. [CrossRef] [PubMed]

5. Tamura, T.; Yoshioka, Y.; Sakamoto, S.; Ichikawa, T.; Ochiya, T. Extracellular Vesicles in Bone Metastasis: Key Players in the Tumor Microenvironment and Promising Therapeutic Targets. Int. J. Mol. Sci. 2020, 21, 6680. [CrossRef] [PubMed]

6. Kaplan, R.N.; Rafii, S.; Lyden, D. Preparing the "soil": The premetastatic niche. Cancer Res. 2006, 66, 11089-11093. [CrossRef] [PubMed]

7. Tamma, R.; Guidolin, D.; Annese, T.; Tortorella, C.; Ruggieri, S.; Rega, S.; Zito, F.A.; Nico, B.; Ribatti, D. Spatial distribution of mast cells and macrophages around tumor glands in human breast ductal carcinoma. Exp. Cell Res. 2017, 359, 179-184. [CrossRef]

8. Tamma, R.; Ruggieri, S.; Annese, T.; Simone, G.; Mangia, A.; Rega, S.; Zito, F.A.; Nico, B.; Ribatti, D. Bcl6/p53 expression, macrophages/mast cells infiltration and microvascular density in invasive breast carcinoma. Oncotarget 2018, 9, 22727-22740. [CrossRef]

9. Langley, R.R.; Fidler, I.J. The seed and soil hypothesis revisited-The role of tumor-stroma interactions in metastasis to different organs. Int. J. Cancer 2011, 128, 2527-2535. [CrossRef]

10. Paget, S. The distribution of secondary growths in cancer of the breast. Lancet 1889, 133, 571-573. [CrossRef]

11. Kraljevic Pavelic, S.; Sedic, M.; Bosnjak, H.; Spaventi, S.; Pavelic, K. Metastasis: New perspectives on an old problem. Mol. Cancer 2011, 10, 22. [CrossRef] [PubMed]

12. Guise, T.A. The vicious cycle of bone metastases. J. Musculoskelet. Neuronal Interact. 2002, 2, 570-572.

13. Schmid-Alliana, A.; Schmid-Antomarchi, H.; Al-Sahlanee, R.; Lagadec, P.; Scimeca, J.C.; Verron, E. Understanding the Progression of Bone Metastases to Identify Novel Therapeutic Targets. Int. J. Mol. Sci. 2018, 19, 148. [CrossRef]

14. Keller, E.T.; Zhang, J.; Cooper, C.R.; Smith, P.C.; McCauley, L.K.; Pienta, K.J.; Taichman, R.S. Prostate carcinoma skeletal metastases: Cross-talk between tumor and bone. Cancer Metastasis Rev. 2001, 20, 333-349. [CrossRef]

15. Coleman, R.E.; Seaman, J.J. The role of zoledronic acid in cancer: Clinical studies in the treatment and prevention of bone metastases. Semin. Oncol. 2001, 28, 11-16. [CrossRef]

16. Chen, J.L.; Gurski, R.R.; Takahashi, K.; Andersson, R. Gastrointestinal cancer metastasis. Gastroenterol. Res. Pract. 2012, 2012, 415498. [CrossRef] [PubMed]

17. Gomi, D.; Fukushima, T.; Kobayashi, T.; Sekiguchi, N.; Sakamoto, A.; Mamiya, K.; Koizumi, T. Gastric cancer initially presenting as bone metastasis: Two case reports and a literature review. Oncol. Lett. 2018, 16, 5863-5867. [CrossRef]

18. Urata, S.; Izumi, K.; Hiratsuka, K.; Maolake, A.; Natsagdorj, A.; Shigehara, K.; Iwamoto, H.; Kadomoto, S.; Makino, T.; Naito, R.; et al. C-C motif ligand 5 promotes migration of prostate cancer cells in the prostate cancer bone metastasis microenvironment. Cancer Sci. 2018, 109, 724-731. [CrossRef] [PubMed]

19. Hall, C.L.; Bafico, A.; Dai, J.; Aaronson, S.A.; Keller, E.T. Prostate cancer cells promote osteoblastic bone metastases through Wnts. Cancer Res. 2005, 65, 7554-7560. [CrossRef]

20. Mohammed, M.K.; Shao, C.; Luu, H.H.; Haydon, R.C. Opening the LOX to bone metastasis: The role of secreted lysyl oxidase in skeletal recurrence of breast cancers. Genes Dis. 2015, 2, 288-290. [CrossRef] 
21. Cowan, R.W.; Singh, G.; Ghert, M. PTHrP increases RANKL expression by stromal cells from giant cell tumor of bone. J. Orthop. Res. 2012, 30, 877-884. [CrossRef]

22. Kwan Tat, S.; Padrines, M.; Theoleyre, S.; Heymann, D.; Fortun, Y. IL-6, RANKL, TNF-alpha/IL-1: Interrelations in bone resorption pathophysiology. Cytokine Growth Factor Rev. 2004, 15, 49-60. [CrossRef] [PubMed]

23. Mundy, G.R. Mechanisms of bone metastasis. Cancer 1997, 80, 1546-1556. [CrossRef]

24. Ghobrial, I.M. Myeloma as a model for the process of metastasis: Implications for therapy. Blood 2012, 120, 20-30. [CrossRef] [PubMed]

25. Ma, X.; Yu, J. Role of the bone microenvironment in bone metastasis of malignant tumors-Therapeutic implications. Cell Oncol. 2020. [CrossRef]

26. Mansoorinasab, M.; Abdolhoseinpour, H. A review and update of vertebral fractures due to metastatic tumors of various sites to the spine: Percutaneous vertebroplasty. Interv. Med. Appl. Sci. 2018, 10, 1-6. [CrossRef]

27. Zhang, X.; Xiang, J. Remodeling the Microenvironment before Occurrence and Metastasis of Cancer. Int. J. Biol. Sci. 2019, 15, 105-113. [CrossRef]

28. Saki, N.; Abroun, S.; Farshdousti Hagh, M.; Asgharei, F. Neoplastic bone marrow niche: Hematopoietic and mesenchymal stem cells. Cell J. 2011, 13, 131-136.

29. Tamma, R.; Ribatti, D. Bone Niches, Hematopoietic Stem Cells, and Vessel Formation. Int. J. Mol. Sci. 2017, 18, 151. [CrossRef]

30. Kurenkova, A.D.; Medvedeva, E.V.; Newton, P.T.; Chagin, A.S. Niches for Skeletal Stem Cells of Mesenchymal Origin. Front. Cell Dev. Biol. 2020, 8, 592. [CrossRef]

31. Arai, F.; Hosokawa, K.; Toyama, H.; Matsumoto, Y.; Suda, T. Role of N-cadherin in the regulation of hematopoietic stem cells in the bone marrow niche. Ann. N. Y. Acad. Sci. 2012, 1266, 72-77. [CrossRef] [PubMed]

32. Taverna, S.; Giusti, I.; D'Ascenzo, S.; Pizzorno, L.; Dolo, V. Breast Cancer Derived Extracellular Vesicles in Bone Metastasis Induction and Their Clinical Implications as Biomarkers. Int. J. Mol. Sci. 2020, 21, 3573. [CrossRef] [PubMed]

33. Kaplan, R.N.; Psaila, B.; Lyden, D. Niche-to-niche migration of bone-marrow-derived cells. Trends Mol. Med. 2007, 13, 72-81. [CrossRef]

34. Ratajczak, M.Z.; Ratajczak, J.; Machalinski, B.; Majka, M.; Marlicz, W.; Carter, A.; Pietrzkowski, Z.; Gewirtz, A.M. Role of vascular endothelial growth factor (VEGF) and placenta-derived growth factor (PlGF) in regulating human haemopoietic cell growth. Br. J. Haematol. 1998, 103, 969-979. [CrossRef] [PubMed]

35. List, A.F.; Glinsmann-Gibson, B.; Stadheim, C.; Meuillet, E.J.; Bellamy, W.; Powis, G. Vascular endothelial growth factor receptor-1 and receptor-2 initiate a phosphatidylinositide 3-kinase-dependent clonogenic response in acute myeloid leukemia cells. Exp. Hematol. 2004, 32, 526-535. [CrossRef]

36. Ceci, C.; Atzori, M.G.; Lacal, P.M.; Graziani, G. Role of VEGFs/VEGFR-1 Signaling and its Inhibition in Modulating Tumor Invasion: Experimental Evidence in Different Metastatic Cancer Models. Int. J. Mol. Sci. 2020, 21, 1388. [CrossRef]

37. Arai, F.; Hirao, A.; Suda, T. Regulation of hematopoietic stem cells by the niche. Trends Cardiovasc. Med. 2005, 15, 75-79. [CrossRef] [PubMed]

38. Haider, M.T.; Holen, I.; Dear, T.N.; Hunter, K.; Brown, H.K. Modifying the osteoblastic niche with zoledronic acid in vivo-potential implications for breast cancer bone metastasis. Bone 2014, 66, 240-250. [CrossRef]

39. Kolb, A.D.; Shupp, A.B.; Mukhopadhyay, D.; Marini, F.C.; Bussard, K.M. Osteoblasts are "educated" by crosstalk with metastatic breast cancer cells in the bone tumor microenvironment. Breast Cancer Res. 2019, 21, 31. [CrossRef]

40. Zhou, J.; Wang, X.H.; Zhao, Y.X.; Chen, C.; Xu, X.Y.; Sun, Q.; Wu, H.Y.; Chen, M.; Sang, J.F.; Su, L.; et al. Cancer-Associated Fibroblasts Correlate with Tumor-Associated Macrophages Infiltration and Lymphatic Metastasis in Triple Negative Breast Cancer Patients. J. Cancer 2018, 9, 4635-4641. [CrossRef]

41. Hanahan, D.; Weinberg, R.A. Hallmarks of cancer: The next generation. Cell 2011, 144, 646-674. [CrossRef] [PubMed]

42. Hanahan, D.; Weinberg, R.A. The hallmarks of cancer. Cell 2000, 100, 57-70. [CrossRef] 
43. Mishra, P.J.; Mishra, P.J.; Humeniuk, R.; Medina, D.J.; Alexe, G.; Mesirov, J.P.; Ganesan, S.; Glod, J.W.; Banerjee, D. Carcinoma-associated fibroblast-like differentiation of human mesenchymal stem cells. Cancer Res. 2008, 68, 4331-4339. [CrossRef]

44. Wang, M.; Yang, X.; Wei, M.; Wang, Z. The Role of CXCL12 Axis in Lung Metastasis of Colorectal Cancer. J. Cancer 2018, 9, 3898-3903. [CrossRef]

45. Zhang, R.; Pan, X.; Huang, Z.; Weber, G.F.; Zhang, G. Osteopontin enhances the expression and activity of MMP-2 via the SDF-1/CXCR4 axis in hepatocellular carcinoma cell lines. PLoS ONE 2011, 6, e23831. [CrossRef]

46. Perissinotto, E.; Cavalloni, G.; Leone, F.; Fonsato, V.; Mitola, S.; Grignani, G.; Surrenti, N.; Sangiolo, D.; Bussolino, F.; Piacibello, W.; et al. Involvement of chemokine receptor 4/stromal cell-derived factor 1 system during osteosarcoma tumor progression. Clin. Cancer Res. 2005, 11, 490-497.

47. Burger, J.A.; Kipps, T.J. CXCR4: A key receptor in the crosstalk between tumor cells and their microenvironment. Blood 2006, 107, 1761-1767. [CrossRef]

48. Shevde, L.A.; Das, S.; Clark, D.W.; Samant, R.S. Osteopontin: An effector and an effect of tumor metastasis. Curr. Mol. Med. 2010, 10, 71-81. [CrossRef]

49. Nilsson, S.K.; Johnston, H.M.; Whitty, G.A.; Williams, B.; Webb, R.J.; Denhardt, D.T.; Bertoncello, I.; Bendall, L.J.; Simmons, P.J.; Haylock, D.N. Osteopontin, a key component of the hematopoietic stem cell niche and regulator of primitive hematopoietic progenitor cells. Blood 2005, 106, 1232-1239. [CrossRef]

50. Zeng, Z.; Shi, Y.X.; Samudio, I.J.; Wang, R.Y.; Ling, X.; Frolova, O.; Levis, M.; Rubin, J.B.; Negrin, R.R.; Estey, E.H.; et al. Targeting the leukemia microenvironment by CXCR4 inhibition overcomes resistance to kinase inhibitors and chemotherapy in AML. Blood 2009, 113, 6215-6224. [CrossRef] [PubMed]

51. Williams, C.K.; Segarra, M.; Sierra Mde, L.; Sainson, R.C.; Tosato, G.; Harris, A.L. Regulation of CXCR4 by the Notch ligand delta-like 4 in endothelial cells. Cancer Res. 2008, 68, 1889-1895. [CrossRef] [PubMed]

52. Wang, W.; Yu, S.; Zimmerman, G.; Wang, Y.; Myers, J.; Yu, V.W.; Huang, D.; Huang, X.; Shim, J.; Huang, Y.; et al. Notch Receptor-Ligand Engagement Maintains Hematopoietic Stem Cell Quiescence and Niche Retention. Stem Cells 2015, 33, 2280-2293. [CrossRef]

53. Rodilla, V.; Villanueva, A.; Obrador-Hevia, A.; Robert-Moreno, A.; Fernandez-Majada, V.; Grilli, A.; Lopez-Bigas, N.; Bellora, N.; Alba, M.M.; Torres, F.; et al. Jagged1 is the pathological link between Wnt and Notch pathways in colorectal cancer. Proc. Natl. Acad. Sci. USA 2009, 106, 6315-6320. [CrossRef] [PubMed]

54. Wang, Y.; Krivtsov, A.V.; Sinha, A.U.; North, T.E.; Goessling, W.; Feng, Z.; Zon, L.I.; Armstrong, S.A. The Wnt/beta-catenin pathway is required for the development of leukemia stem cells in AML. Science 2010, 327, 1650-1653. [CrossRef] [PubMed]

55. Dick, J.E. Stem cell concepts renew cancer research. Blood 2008, 112, 4793-4807. [CrossRef] [PubMed]

56. Cao, H.; Cao, B.; Heazlewood, C.K.; Domingues, M.; Sun, X.; Debele, E.; McGregor, N.E.; Sims, N.A.; Heazlewood, S.Y.; Nilsson, S.K. Osteopontin is An Important Regulative Component of the Fetal Bone Marrow Hematopoietic Stem Cell Niche. Cells 2019, 8, 985. [CrossRef] [PubMed]

57. Bellahcene, A.; Castronovo, V.; Ogbureke, K.U.; Fisher, L.W.; Fedarko, N.S. Small integrin-binding ligand N-linked glycoproteins (SIBLINGs): Multifunctional proteins in cancer. Nat. Rev. Cancer 2008, 8, 212-226. [CrossRef]

58. Ang, C.; Chambers, A.F.; Tuck, A.B.; Winquist, E.; Izawa, J.I. Plasma osteopontin levels are predictive of disease stage in patients with transitional cell carcinoma of the bladder. BJU Int. 2005, 96, 803-805. [CrossRef]

59. Decker, A.M.; Jung, Y.; Cackowski, F.; Taichman, R.S. The role of hematopoietic stem cell niche in prostate cancer bone metastasis. J. Bone Oncol. 2016, 5, 117-120. [CrossRef]

60. Schuettpelz, L.G.; Link, D.C. Niche competition and cancer metastasis to bone. J. Clin. Investig. 2011, 121, 1253-1255. [CrossRef]

61. Glinsky, V.V. Intravascular cell-to-cell adhesive interactions and bone metastasis. Cancer Metastasis Rev. 2006, 25, 531-540. [CrossRef] [PubMed]

62. Hu, C.; Wen, J.; Gong, L.; Chen, X.; Wang, J.; Hu, F.; Zhou, Q.; Liang, J.; Wei, L.; Shen, Y.; et al. Thrombospondin-1 promotes cell migration, invasion and lung metastasis of osteosarcoma through FAK dependent pathway. Oncotarget 2017, 8, 75881-75892. [CrossRef] [PubMed]

63. Esteban, S.; Clemente, C.; Koziol, A.; Gonzalo, P.; Rius, C.; Martinez, F.; Linares, P.M.; Chaparro, M.; Urzainqui, A.; Andres, V.; et al. Endothelial MT1-MMP targeting limits intussusceptive angiogenesis and colitis via TSP1/nitric oxide axis. EMBO Mol. Med. 2020, 12, e10862. [CrossRef] 
64. Bornstein, P. Thrombospondins function as regulators of angiogenesis. J. Cell Commun. Signal. 2009, 3, 189-200. [CrossRef]

65. Ghajar, C.M.; Peinado, H.; Mori, H.; Matei, I.R.; Evason, K.J.; Brazier, H.; Almeida, D.; Koller, A.; Hajjar, K.A.; Stainier, D.Y.; et al. The perivascular niche regulates breast tumour dormancy. Nat. Cell Biol. 2013, 15, 807-817. [CrossRef]

66. Horiuchi, K.; Amizuka, N.; Takeshita, S.; Takamatsu, H.; Katsuura, M.; Ozawa, H.; Toyama, Y.; Bonewald, L.F.; Kudo, A. Identification and characterization of a novel protein, periostin, with restricted expression to periosteum and periodontal ligament and increased expression by transforming growth factor beta. J. Bone Miner. Res. 1999, 14, 1239-1249. [CrossRef] [PubMed]

67. Okazaki, T.; Tamai, K.; Shibuya, R.; Nakamura, M.; Mochizuki, M.; Yamaguchi, K.; Abe, J.; Takahashi, S.; Sato, I.; Kudo, A.; et al. Periostin is a negative prognostic factor and promotes cancer cell proliferation in non-small cell lung cancer. Oncotarget 2018, 9, 31187-31199. [CrossRef]

68. Yang, J.; Weinberg, R.A. Epithelial-mesenchymal transition: At the crossroads of development and tumor metastasis. Dev. Cell 2008, 14, 818-829. [CrossRef]

69. Banyard, J.; Bielenberg, D.R. The role of EMT and MET in cancer dissemination. Connect Tissue Res. 2015, 56, 403-413. [CrossRef]

70. Ocana, O.H.; Corcoles, R.; Fabra, A.; Moreno-Bueno, G.; Acloque, H.; Vega, S.; Barrallo-Gimeno, A.; Cano, A.; Nieto, M.A. Metastatic colonization requires the repression of the epithelial-mesenchymal transition inducer Prrx1. Cancer Cell 2012, 22, 709-724. [CrossRef]

71. Tsubakihara, Y.; Moustakas, A. Epithelial-Mesenchymal Transition and Metastasis under the Control of Transforming Growth Factor beta. Int. J. Mol. Sci. 2018, 19, 3672. [CrossRef] [PubMed]

72. Lim, J.; Thiery, J.P. Epithelial-mesenchymal transitions: Insights from development. Development 2012, 139, 3471-3486. [CrossRef]

73. Deng, W.; Fernandez, A.; McLaughlin, S.L.; Klinke, D.J., 2nd. WNT1-inducible signaling pathway protein 1 (WISP1/CCN4) stimulates melanoma invasion and metastasis by promoting the epithelial-mesenchymal transition. J. Biol. Chem. 2019, 294, 5261-5280. [CrossRef]

74. Ongkeko, W.M.; Burton, D.; Kiang, A.; Abhold, E.; Kuo, S.Z.; Rahimy, E.; Yang, M.; Hoffman, R.M.; Wang-Rodriguez, J.; Deftos, L.J. Parathyroid hormone related-protein promotes epithelial-to-mesenchymal transition in prostate cancer. PLoS ONE 2014, 9, e85803. [CrossRef] [PubMed]

75. Soki, F.N.; Park, S.I.; McCauley, L.K. The multifaceted actions of PTHrP in skeletal metastasis. Future Oncol. 2012, 8, 803-817. [CrossRef] [PubMed]

76. Liu, J.; Sun, X.; Qin, S.; Wang, H.; Du, N.; Li, Y.; Pang, Y.; Wang, C.; Xu, C.; Ren, H. CDH1 promoter methylation correlates with decreased gene expression and poor prognosis in patients with breast cancer. Oncol. Lett. 2016, 11, 2635-2643. [CrossRef]

77. Ye, T.; Li, J.; Sun, Z.; Liu, D.; Zeng, B.; Zhao, Q.; Wang, J.; Xing, H.R. Cdh1 functions as an oncogene by inducing self-renewal of lung cancer stem-like cells via oncogenic pathways. Int. J. Biol. Sci. 2020, 16, 447-459. [CrossRef]

78. Shiozawa, Y.; Pedersen, E.A.; Havens, A.M.; Jung, Y.; Mishra, A.; Joseph, J.; Kim, J.K.; Patel, L.R.; Ying, C.; Ziegler, A.M.; et al. Human prostate cancer metastases target the hematopoietic stem cell niche to establish footholds in mouse bone marrow. J. Clin. Investig. 2011, 121, 1298-1312. [CrossRef]

79. Esposito, M.; Mondal, N.; Greco, T.M.; Wei, Y.; Spadazzi, C.; Lin, S.C.; Zheng, H.; Cheung, C.; Magnani, J.L.; Lin, S.H.; et al. Bone vascular niche E-selectin induces mesenchymal-epithelial transition and Wnt activation in cancer cells to promote bone metastasis. Nat. Cell Biol. 2019, 21, 627-639. [CrossRef]

80. Yin, T.; Li, L. The stem cell niches in bone. J. Clin. Investig. 2006, 116, 1195-1201. [CrossRef]

81. Doglioni, G.; Parik, S.; Fendt, S.M. Interactions in the (Pre)metastatic Niche Support Metastasis Formation. Front. Oncol. 2019, 9, 219. [CrossRef]

82. Uy, G.L.; Rettig, M.P.; Motabi, I.H.; McFarland, K.; Trinkaus, K.M.; Hladnik, L.M.; Kulkarni, S.; Abboud, C.N.; Cashen, A.F.; Stockerl-Goldstein, K.E.; et al. A phase 1/2 study of chemosensitization with the CXCR4 antagonist plerixafor in relapsed or refractory acute myeloid leukemia. Blood 2012, 119, 3917-3924. [CrossRef] [PubMed]

83. Cho, B.S.; Kim, H.J.; Konopleva, M. Targeting the CXCL12/CXCR4 axis in acute myeloid leukemia: From bench to bedside. Korean J. Intern. Med. 2017, 32, 248-257. [CrossRef] [PubMed] 
84. Lucas, D.; Scheiermann, C.; Chow, A.; Kunisaki, Y.; Bruns, I.; Barrick, C.; Tessarollo, L.; Frenette, P.S. Chemotherapy-induced bone marrow nerve injury impairs hematopoietic regeneration. Nat. Med. 2013, 19, 695-703. [CrossRef]

85. Shao, L.; Luo, Y.; Zhou, D. Hematopoietic stem cell injury induced by ionizing radiation. Antioxid. Redox Signal. 2014, 20, 1447-1462. [CrossRef]

86. Duan, C.W.; Shi, J.; Chen, J.; Wang, B.; Yu, Y.H.; Qin, X.; Zhou, X.C.; Cai, Y.J.; Li, Z.Q.; Zhang, F.; et al. Leukemia propagating cells rebuild an evolving niche in response to therapy. Cancer Cell 2014, 25, 778-793. [CrossRef]

87. Boyerinas, B.; Zafrir, M.; Yesilkanal, A.E.; Price, T.T.; Hyjek, E.M.; Sipkins, D.A. Adhesion to osteopontin in the bone marrow niche regulates lymphoblastic leukemia cell dormancy. Blood 2013, 121, 4821-4831. [CrossRef]

88. Celia-Terrassa, T.; Kang, Y. Metastatic niche functions and therapeutic opportunities. Nat. Cell Biol. 2018, 20, 868-877. [CrossRef] [PubMed]

89. Yamamoto, M.; Kikuchi, H.; Ohta, M.; Kawabata, T.; Hiramatsu, Y.; Kondo, K.; Baba, M.; Kamiya, K.; Tanaka, T.; Kitagawa, M.; et al. TSU68 prevents liver metastasis of colon cancer xenografts by modulating the premetastatic niche. Cancer Res. 2008, 68, 9754-9762. [CrossRef]

Publisher's Note: MDPI stays neutral with regard to jurisdictional claims in published maps and institutional affiliations.

(C) 2020 by the authors. Licensee MDPI, Basel, Switzerland. This article is an open access article distributed under the terms and conditions of the Creative Commons Attribution (CC BY) license (http://creativecommons.org/licenses/by/4.0/). 